\title{
Consensus
}

Volume 30

Issue 1 Globalization

Article 17

$5-1-2005$

\section{Christian contradictions: the structures of Lutheran and Catholic thought}

Allen Jorgenson

ajorgenson@wlu.ca

Follow this and additional works at: https://scholars.wlu.ca/consensus

\section{Recommended Citation}

Jorgenson, Allen (2005) "Christian contradictions: the structures of Lutheran and Catholic thought ," Consensus: Vol. 30 : Iss. 1 , Article 17.

Available at: https://scholars.wlu.ca/consensus/vol30/iss1/17

This Book Reviews is brought to you for free and open access by Scholars Commons @ Laurier. It has been accepted for inclusion in Consensus by an authorized editor of Scholars Commons @ Laurier. For more information, please contact scholarscommons@wlu.ca. 
Although the author provides the social and political setting for these three ordained women, biography has a way of overwhelming this framework. To be sure, though authors have the freedom to choose their emphases, I think that the work could stand a little more context to give the biographies more life. However, my main critique takes up the issue of style. The book has some of the ponderous quality of a dissertation. More judicious editing would have produced a smoother work that could have been more literarily engaging. In spite of these weaknesses, the over-all strength and value of the book renders it an important work in that field which celebrates the triumph of women on their long and all too often lonely march to justice. I was brought to tears by ZinkSawyer's portrayal of the blind Antoinette Brown Blackwell being led (at age 95) into the booth by her daughter to cast her ballot in the first American federal election where women had the right to vote.

Oscar Cole-Arnal

Waterloo Lutheran Seminary

\section{Christian Contradictions:}

\section{The Structures of Lutheran and Catholic Thought}

Daphne Hampson

Cambridge: Cambridge University Press, 2001

323 Pages, $\$ 90.00$ Hardcover

Daphne Hampson has written a book profoundly valuable for ecumenists and others interested in the challenges inherent in ecumenical dialogue. She advances the thesis that structures of thought are of fundamental import for theology, and that an adequate apprehension of doctrine is only possible in relationship to these structures. Hampson concludes that Lutheran and Roman Catholic structures of thoughts are strictly incomparable insofar as a paradigm shift separates one from the other. She proposes that attempts to reconcile differing structures of thought, such as the Joint Declaration on the Doctrine of Justification (1999), finally demonstrate this incomparability.

Hampson first explicates Luther's notion of justification. She does a fine job of demonstrating the dialectical character of Luther's 
thought and nicely articulates his picture of the Christian as the one who lives extra se - "outside herself." As Paul puts it in Col. 3:3: "for you have died, and your life is hidden with Christ in God." The Christian simultaneously lives coram deo - "before God" in selfinterested sin and by faith extra se. In the second chapter, Hampson contrasts this vision with that proposed by Roman Catholic thought. The thought of Catholicism is deemed linear, and the transformation of nature by grace is one in which order is restored rather than creation made altogether new. Hampson helpfully exegetes both the text and context of Trent in order to demonstrate that anything approaching a Lutheran perspective was intentionally excluded by the council. This is followed by a chapter in which Hampson outlines common misapprehensions of Lutheran thought by Roman Catholics, paying particular attention to the manner in which they fail to see that justification by grace through faith is first understood by Lutherans as a hermeneutic. In the fourth chapter she uses the example of Anders Nygren as a test case in which to demonstrate her thesis, which is well developed as she begins to explicate the Joint Declaration in the fifth chapter. Her careful historical analysis of the celebrated opposition to the declaration by both Lutherans and Roman Catholics underscores her conviction that Roman Catholic concessions demonstrate betrayal of the normative claims of Trent and Lutheran concessions suggest a very un-Lutheran interest in positing the possibility of a subject in whom the old and new Adam exist in continuity. The declaration fails, in her estimation, because basic language, like "justification" and "grace" mean drastically different things to the colloquers.

In the sixth chapter she demonstrates the perduring appeal of a Lutheran paradigm and proposes Bultmann's as an example par excellence of a faithful application of the Lutheran hermeneutic in modernity. Bultmann, however, finally fails in that the subject in his thought is not adequately constructed by relationships and the possibility of the transformation of the self is eclipsed by the radical discontinuity of living from the future in apposition to the past. Bultmann fails to answer the Roman Catholic call for the necessity of love and its attending need for a self-consistent subject. In the seventh chapter, Hampson proposes Kierkegaard as the thinker most likely to synthesize the Roman Catholic emphasis on love with the Lutheran emphasis on faith. Kierkegaard's subject is only related to the self by 
first relating to the Source of self. The subject of Kierkegaard's thought then returns to itself in the realm of ethics. Unlike Luther, in Hampson's estimation, Kierkegaard more clearly makes a case for a self-constitution which implies loving the neighbour.

Hampson writes as a post-Christian feminist. She is convinced that Roman Catholic and Lutheran ecumenists, in general, fail from the outset by not respecting different structures of thought. More importantly, in her estimation, they finally fail because the backdrop to dialogue has wholly shifted. Ecumenists have utterly ignored a more obvious and pressing concern: the crumbling of Christianity. She considers, ultimately, that claims about the uniqueness of Christ are nonsensical in modernity and that debates about justification simply mask this new reality. Unfortunately, this latter critique comes as a something of an appendage to the text proper, although she refers readers to her other works for a more thorough treatment.

While I found the book immensely clear and helpful, I sometimes winced at the generalizations used to advance the thesis of the book. For example, she claims that Lutheranism is a religion of hearing while Catholicism is a religion of sight. While a depiction of the Lutheran church as a Mundhaus is well known, anyone vaguely familiar with Luther will also know that he joins the tradition in asserting the importance of words made visible. Moreover, Hampson has failed to relate, more generally, Luther's sacramental theology to justification, and his treatment of a theology of the cross is really altogether missing. Moreover, Hampson fails to engage, at length, more "catholic" readers of Luther such as Robert Jenson, David Yeago and Reinhard Hütter. Her treatment of the Finnish research on Luther is sketchy and her assertion that Luther is wholly uninterested in "deification" (p. 107) suggests she would benefit by a return to Luther's sermons on John. Despite these concerns, I wholeheartedly recommend this book to readers interested in considering the potentials and perils inherent in ecumenical encounter. The thesis advanced deserves careful consideration and serves well those who realize that the means of ecumenism must be informed by its end.

Allen G. Jorgenson

St. James Lutheran Church

Mannheim, Ontario 